labeled drawing of the dimer; crystal packing is shown in Fig. 2.

Discussion. The dimer is joined across an inversion center by an $\left(\eta^{5}, \eta^{1}\right)-\mathrm{Cp}^{*}$ group which bridges the two symmetry-related Sc atoms. The $\eta^{1}$-methylene (C6) has been formed as the result of $\mathrm{C}-\mathrm{H}$ activation of a $\mathrm{Cp}^{*}$ methyl group. A somewhat surprising result is that, in all other regards, the bonding is very similar to that determined for $\mathrm{Cp}_{2}^{*} \mathrm{ScCH}_{3}$ (Thompson et al., 1987). The $\left(\eta^{5}, \eta^{1}\right)$-ring remains planar with a maximum deviation of only $0.22 \AA$ from the least-squares plane calculated for $\mathrm{Cl}$ through $\mathrm{C} 10$. The geometry about $\mathrm{C} 6$ is essentially tetrahedral; the angles $\mathrm{Cl}-\mathrm{C} 6-\mathrm{Sc}^{\prime}, \mathrm{Cl}-\mathrm{C} 6-\mathrm{H} 6 A$, $\mathrm{C} 1-\mathrm{C} 6-\mathrm{H} 6 B$ and $\mathrm{H} 6 A-\mathrm{C} 6-\mathrm{H} 6 B$ are 118.9 , $107.3,104.8$ and $98.1^{\circ}$, respectively, giving an average value of $107.3(8.6)^{\circ}$. The $\mathrm{H} 6 A-\mathrm{C} 6-\mathrm{H} 6 B$ angle is slightly compressed $\left(98.1^{\circ}\right)$ while the $\mathrm{C} 1-\mathrm{C} 6-\mathrm{Sc}^{\prime}$ angle is somewhat opened $\left(118.9^{\circ}\right)$. The $\mathrm{Sc}^{\prime} \cdots \mathrm{H} 6 A$ and $\mathrm{Sc}^{\prime} \cdots \mathrm{H} 6 B$ distances are $2.76(3)$ and $2.79(3) \AA$ indicating that there is no agostic interaction for the $\alpha-\mathrm{H}$ atoms with the $\mathrm{Sc}$ center. The $\mathrm{Cp}^{*}-\mathrm{Sc}-\mathrm{Cp}^{*}$ angle $\left(141.8^{\circ}\right)$ is approximately the same as for $\mathrm{Cp}_{2}^{*}$
$\mathrm{ScCH}_{3}\left(144.7^{\circ}\right)$ suggesting that formal replacement of a methyl ligand with a bulkier $\left(\eta^{5}, \eta^{1}\right)$-Cp* group as the alkyl does not significantly perturb the $\mathrm{Sc}-\mathrm{Cp}^{*}$ bonding.

This work was supported by the USDOE Office of Basic Energy Sciences (Grant No. DE-FG0385ER 113431).

\section{References}

Burger, B. J., Thompson, M. E., Cotter, W. D. \& Bercaw, J. E. (1990). J. Am. Chem. Soc. 112, 1566-1577.

CROMER, D. T. (1974). International Tables for X-ray Crystallography, Vol. IV, pp. 149-151. Birmingham: Kynoch Press. (Present distributor Kluwer Academic Publishers, Dordrecht.)

Cromer, D. T. \& WABER, J. T. (1974). International Tables for $X$-ray Crystallography, Vol. IV, pp. 99-101. Birmingham: Kynoch Press. (Present distributor Kluwer Academic Publishers, Dordrecht.)

DUCHAMP, D. J. (1964). CRYM crystallographic computing system. Am. Crystallogr. Assoc. Meet., Bozeman, Montana. Paper B14, p. 29.

JoHNSON, C. K. (1976). ORTEPII. Report ORNL-3794, third revision. Oak Ridge National Laboratory, Tennessee, USA.

Thompson, M. E., Baxter, S. M., Bulls, A. R., Burger, B. J., Nolan, M. C., Santarsiero, B. D., Schaefer, W. P. \& BerCaw, J. E. (1987). J. Am. Chem. Soc. 109, 203-219.

Acta Cryst. (1992). C48, 1773-1776

\title{
A Silicon-Bridged Bis(substituted Cp) Yttrium Complex
}

\author{
By Richard E. Marsh, William P. Schaefer, E. Bryan Coughlin and John E. Bercaw \\ Division of Chemistry and Chemical Engineering* and The Beckman Institute, Mail Code 139-74, \\ California Institute of Technology, Pasadena, California 91125, USA
}

(Received 9 December 1991; accepted 11 February 1992)

\begin{abstract}
B i s(t e t r a h y d r o f u r a n) l i t h i u m ~[b i s(2-$ trimethylsilyl-4-tert-butyl- $\eta^{5}$-cyclopentadienyl)dimethylsilane]dichloroyttrate, $\left[\mathrm{Li}\left(\mathrm{C}_{4} \mathrm{H}_{8} \mathrm{O}\right)_{2}\right]\left[\mathrm{Y}\left(\mathrm{C}_{26} \mathrm{H}_{48}-\right.\right.$ $\left.\left.\mathrm{Si}_{3}\right) \mathrm{Cl}_{2}\right], M_{r}=755.87$, triclinic, $P \overline{\mathrm{I}}, a=13.110(8), b$ $=17.163$ (15), $c=20.623$ (14) $\AA, \alpha=104.02$ (7), $\beta=$ $99.38(5), \quad \gamma=100.24(6)^{\circ}, \quad V=4326(6) \AA^{3}, \quad Z=4$, $D_{x}=1.16 \mathrm{~g} \mathrm{~cm}^{-3}, \quad \lambda(\mathrm{Mo} K \alpha)=0.71073 \AA, \quad \mu=$ $15.86 \mathrm{~cm}^{-1}, F(000)=1608$, room temperature, $R=$ 0.056 for 6136 reflections with $F_{o}^{2}>3 \sigma\left(F_{o}^{2}\right)$. There are two virtually identical molecules in the asymmetric unit. In each, the $Y$ atom is tetrahedrally coordinated to a substituted Si-bridged bis(cyclopentadienyl) ligand and to two $\mathrm{Cl}$ ions in the cleft. The $\mathrm{Li}$ atom is $2.35 \AA$ from each $\mathrm{Cl}$ ion, and two molecules of tetrahydrofuran are connected to the $\mathrm{Li}$, completing its tetrahedral coordination.
\end{abstract}

* Contribution No. 8539 .

0108-2701/92/101773-04\$06.00
Introduction. The Ziegler-Natta polymerization of olefins has occupied the attention of chemists for nearly four decades. Recently, the development of homogeneous transition-metal catalyst systems has afforded the possibility of mechanistic investigations into various key steps of polymer initiation, propagation and chain termination. Brintzinger and coworkers have developed a series of ansa-zirconocene catalysts which possess a $C_{2}$ symmetric ligand arrangement about the metal center (Roll, Brintzinger, Rieger \& Zolk, 1990; Wiesenfeldt, Reinmuth, Barsties, Evertz \& Brintzinger, 1989). Moreover, activation of these ansa-zirconocene catalysts with methylalumoxane results in production of highly isospecific polymers. Work in this laboratory has centered on the study of well defined singlecomponent Ziegler-Natta-type catalyst systems (Piers, Shapiro, Bunel \& Bercaw, 1990). We report

(C) 1992 International Union of Crystallography 
Table 1. Final heavy-atom coordinates $\left(\times 10^{4}\right)$ and equivalent isotropic displacement parameters

$$
\begin{gathered}
\left(\AA^{2} \times 10^{4}\right) \\
U_{\mathrm{eq}}=(1 / 3) \sum_{i} \sum_{j} U_{i j} a_{i}^{*} a_{j}{ }^{*} \mathbf{a}_{i} \cdot \mathbf{a}_{j} .
\end{gathered}
$$

\begin{tabular}{|c|c|c|c|c|c|c|c|c|}
\hline$x$ & $y$ & $z$ & $U$ & $\mathrm{O} 2 b$ & 3806 (4) & 5367 (3) & 713 (3) & $1018(17)$ \\
\hline $1810(4)$ & $7217(3)$ & 4009 (3) & 432 (9) & C32b & $\begin{array}{l}3480(7) \\
2784(9)\end{array}$ & $\begin{array}{l}3239(5) \\
5833(8)\end{array}$ & $\begin{array}{r}-5(5) \\
-63\end{array}$ & $\begin{array}{l}1193(31) \\
1821\end{array}$ \\
\hline 3262 (1) & 6960 (1) & 3292 (1) & 719 (5) & C $33 b$ & 3178 (10) & $6511(7)$ & $561(8)$ & $\begin{array}{l}1821(31) \\
1849(5)\end{array}$ \\
\hline $\begin{array}{l}3202 \text { (I) } \\
2931 \text { (1) }\end{array}$ & $\begin{array}{l}9700(1) \\
8756(1)\end{array}$ & 4442 (I) & 708 (5) & C $34 b$ & $3759(8)$ & $6177(7)$ & $1041(5)$ & $1634(42)$ \\
\hline
\end{tabular}

Ya
C11a
C12a
Sila
Si2a
Si3a
Cla
C2a
C3a
C4a
C5a
C6a
C7a
C $8 a$
C9a
C10a
C11a
C12a
C13a
C14a
C15a
C16a
C17a
C18a
C19a
C20a
C21a
C22a
C23a
C24a
C25a
C26a

Table 1 (cont.)

\begin{tabular}{ll} 
& \multicolumn{1}{c}{$\boldsymbol{x}$} \\
$\mathrm{C} 28 b$ & $6714(13)$ \\
$\mathrm{C} 29 b$ & $6127(15)$ \\
$\mathrm{C} 30 b$ & $5115(7)$ \\
$\mathrm{O} 2 b$ & $3806(4)$ \\
$\mathrm{C} 31 b$ & $3480(7)$ \\
$\mathrm{C} 32 b$ & $2784(9)$ \\
$\mathrm{C} 33 b$ & $3178(10)$ \\
$\mathrm{C} 34 b$ & $3759(8)$
\end{tabular}

$\quad y$
$6188(10)$
$5857(11)$
$5376(6)$
$5367(3)$
$5239(5)$
$5833(8)$
$6511(7)$
$6177(7)$

$z$
$2621(10)$
$3055(8)$
$2646(5)$
$713(3)$
$-5(5)$
$-63(7)$
$561(8)$
$1041(5)$

Table 2. Selected bond distances $(\AA)$ and angles $\left({ }^{\circ}\right)$

$632(5)$
$976(23)$

$976(23)$
$903(21)$

531 (16)

525 (17)

587 (18)

$571(18)$
$1259(29)$

1368 (30)

1038 (26)

696 (21)

1049 (26)

1252 (29)

1177 (26)

475 (17)

508 (16)

523 (18)

$523(18)$
$529(17)$

954 (23)

1240 (29)

$902(23)$

679 (20)

960 (23)

$1043(26)$

1278 (27)

3732 (4)

2585 (4)
450 (2)

642 (4)

1553 (1)

406 (1)

726 (1)

-942 (1)

2530 (1)

297 (3)

1066 (3)

$156(3)$

$-330(3)$

-425 (3)

-28 (3)

330 (3)

$1452(3)$

$-1534(3)$

$-1534(3)$
$-76(3)$

$-76(3)$
$-149(3)$

-728 (3)

525 (3)

$1392(3)$

1949 (3)

2100 (3)

1669 (3)

1230 (3)

2133 (3)

3217 (3)

2931 (3)

1766 (4)

2261 (4)

2056 (4)

1100 (4)

$751(5)$

536 (5)

725 (6)

$632(5)$
765 (19)

627 (18)

441 (16)

535 (18)

578 (18)

496 (17)

463 (16)

997 (22)

1007 (23)

1039 (25)

518 (17)

$797(20)$
$795(20)$

769 (19)

465 (16)

464 (17)

548 (18)

534 (18)

555 (18)

699 (18)

892 (22)

1061 (23)

767 (25)

1257 (32)

$1076(30)$

3729 (5)

3036 (3)

3176 (6)

2520 (11)

2042 (8)

2320 (6)

4200 (3)

3881 (7)

4334 (10)

4969 (9)
$4901(6)$

7242 (17)

6003 (9)

776 (34)

1111 (18)

$1758(44)$
$2677(77)$

2627 (79)

1723 (44)

1040 (19)

2243 (63)

3091 (105)

$2576(83)$

8873 (11)

8994 (5)

$792(33)$

$1161(6)$

1958 (3)

$792(33)$

$1492(40)$

$\begin{array}{lll}2.383 & \mathrm{Y} b-\mathrm{Cp} 1 b & 2.396 \\ 2.385 & \mathrm{Y} b-\mathrm{Cp} 2 b & 2.389 \\ 2.628(2) & \mathrm{Y} b-\mathrm{Cl} b & 2.614(1) \\ 2.642(2) & \mathrm{Y} b-\mathrm{Cl} 2 b & 2.623(2) \\ 2.366(11) & \mathrm{Li} b-\mathrm{Cl} 1 b & 2.377(11) \\ 2.340(11) & \mathrm{Li} b-\mathrm{Cl} 2 b & 2.401(11) \\ 1.917(12) & \mathrm{Li} b-\mathrm{O} b & 1.950(12) \\ 1.925(12) & \mathrm{Li} b-\mathrm{O} 2 b & 1.893(12) \\ 1.869(7) & \mathrm{Si} 1 b-\mathrm{Cl} b & 1.872(6) \\ 1.863(6) & \mathrm{Si} 1 b-\mathrm{C} 2 b & 1.858(6) \\ 1.878(6) & \mathrm{Si} 1 b-\mathrm{C} 3 b & 1.862(5) \\ 1.858(6) & \mathrm{Si} b-\mathrm{Cl} b & 1.887(6) \\ 1.845(6) & \mathrm{Si} 2 b-\mathrm{C} 4 b & 1.843(6) \\ 1.850(8) & \mathrm{Si} 2 b-\mathrm{C} 8 b & 1.869(7) \\ 1.856(8) & \mathrm{Si} 2 b-\mathrm{C} 9 b & 1.868(7) \\ 1.878(7) & \mathrm{Si} 2 b-\mathrm{Cl} b b & 1.859(7) \\ & & \\ 122.1 & \mathrm{Cp} 1 b-\mathrm{Y} b-\mathrm{Cp} 2 b & 122.5 \\ 114.2 & \mathrm{Cp} 1 b-\mathrm{Y} b-\mathrm{Cl} 1 b & 112.4 \\ 107.0 & \mathrm{Cp} 1 b-\mathrm{Y} b-\mathrm{Cl} 2 b & 108.6 \\ 108.6 & \mathrm{Cp} 2 b-\mathrm{Y} b-\mathrm{Cl} 1 b & 108.1 \\ 114.2 & \mathrm{Cp} 2 b-\mathrm{Y} b-\mathrm{Cl} 2 b & 114.3 \\ 84.6(0) & \mathrm{Cl} 1 b-\mathrm{Y} b-\mathrm{Cl} 2 b & 84.6(0) \\ 97.8(4) & \mathrm{Cl} b-\mathrm{Li} b-\mathrm{Cl} 2 b & 95.1(4) \\ 113.7(5) & \mathrm{Cl} 1 b-\mathrm{Li} b-\mathrm{O} 1 b & 107.9(5) \\ 115.5(5) & \mathrm{Cl} b-\mathrm{Li} b-\mathrm{O} 2 b & 117.9(5) \\ 114.3(5) & \mathrm{Cl} 2 b-\mathrm{Li} b-\mathrm{O} 1 b & 120.3(5) \\ 113.9(5) & \mathrm{Cl} 2 b-\mathrm{Li} b-\mathrm{O} 2 b & 113.3(5) \\ 102.4(6) & \mathrm{O} 1 b-\mathrm{Li} b-\mathrm{O} 2 b & 103.0(6) \\ 99.1(3) & \mathrm{Cl} b-\mathrm{Si} 1 b-\mathrm{C} 3 b & 99.5(2) \\ & & \end{array}$

herein the crystal structure of the $C_{2}$ symmetric complex rac- $\left(\mathrm{CH}_{3}\right)_{2} \mathrm{Si}\left[2-\mathrm{Si}\left(\mathrm{CH}_{3}\right)_{3}-4-\mathrm{C}\left(\mathrm{CH}_{3}\right)_{3} \mathrm{C}_{5} \mathrm{H}_{2}\right]_{2}$ $\mathrm{YCl}_{2} \mathrm{Li}\left(\mathrm{OCH}_{2} \mathrm{CH}_{2} \mathrm{CH}_{2} \mathrm{CH}_{2}\right)_{2}$.

Experimental. A crystal with a most irregular triangular prism shape, $0.63 \times 0.67 \times 1.18 \mathrm{~mm}$, was used for data collection on a CAD-4 diffractometer, with $\omega$ scans. 25 reflections with $26<2 \theta<29^{\circ}$ were used for the determination of the cell dimensions. An absorption correction was not applied: $\psi$ scans of six high $\chi$ reflections suggested corrections of $\pm 7 \%$ to $I$, but the corrections resulted in a poorer goodness of fit for merging the data. The crystal was somewhat obscured by grease in its capillary, so no analytical absorption correction could be made; $(\sin \theta / \lambda)_{\max }=$ $0.59 \AA^{-1} ; h$ from -15 to $15, k$ from -20 to $20, l$ from 0 to 24 . Three standard reflections $(1 \overline{25}, \overline{32} 4$ and $15 \overline{2}$ ) showed no variations greater than those predicted by counting statistics. 16018 reflections were measured, of which 15167 were independent. Goodness of fit for merging was 1.35 , and $R_{\text {int }}$ for 372 reflections with exactly two observations was 0.051 . All reflections, $F_{o}^{2}$ positive and negative, were used in solution and refinement of the structure. The structure was solved from a Patterson map, which gave coordinates of $\mathrm{Y}$ atoms; remaining atoms were 
found by successive structure factor-Fourier calculations. $F_{o}^{2}$ values were used in full-matrix leastsquares refinement, with $w=1 / \sigma^{2}\left(F_{o}^{2}\right)$. $\mathrm{H}$ atoms were positioned by calculation $(\mathrm{C}-\mathrm{H}=0.95 \AA$ ) assuming staggered geometries on methyl groups; $\mathrm{H}$-atom parameters were not refined, but the atoms were repositioned near the conclusion of the refinement. $R$ on $F=0.134$ for 12716 reflections with $F_{o}^{2}>0(w R$ on $F^{2}=0.010$ ); $R$ on $F=0.056$ for 6136 reflections with $F_{o}^{2}>3 \sigma\left(F_{o}^{2}\right)\left(w R\right.$ on $\left.F^{2}=0.007\right)$; and $S=1.33$ for 15167 reflections and 775 parameters. Variances $\left[\sigma^{2}\left(F_{o}^{2}\right)\right]$ were derived from counting statistics plus an additional term, $(0.014 I)^{2}$; variances of the merged

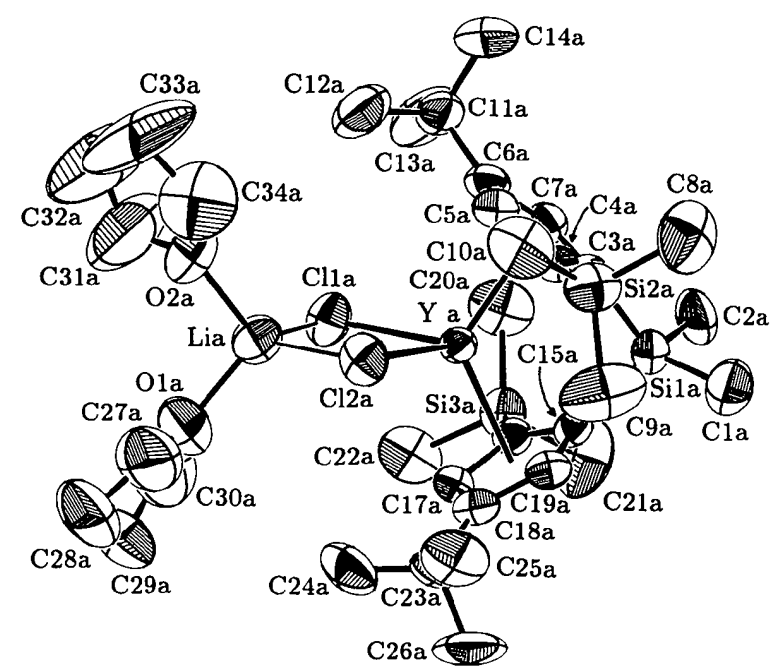

(a)

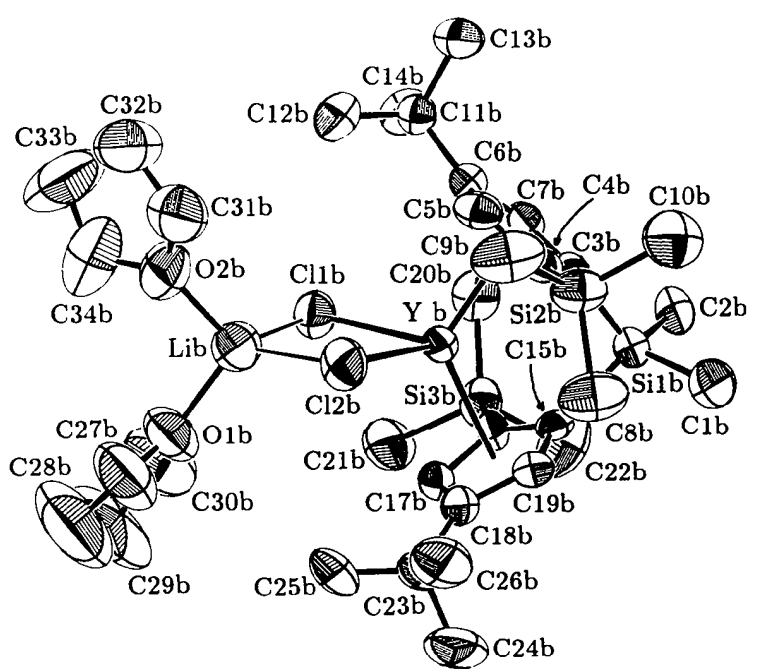

(b)

Fig. 1. An ORTEPII (Johnson, 1976) drawing showing the atomic numbering systems of $(a)$ molecule $A(\mathrm{Cl} 6 a$, between $\mathrm{C} 15 a$ and $\mathrm{C} 17 a$, is not labeled) and (b) molecule $B$ (C16b not labeled). Atoms are shown as $50 \%$ probability ellipsoids, with $\mathrm{H}$ atoms omitted. data by propagation of e.s.d. plus another additional term, $(0.014 \bar{I})^{2}$. In the final cycle, maximum shift/ e.s.d. was 0.09 in the $\mathrm{Y}$ molecule, and 1.56 for $y$ of C32 in thf $a$ [several parameters of this thf group continued to shift (with no change in the residuals) for at least five full-matrix cycles after the remainder of the structure had settled down, presumably because of disorder]. In the final difference map one peak of $1.01 \mathrm{e} \AA^{-3}$ was found near $\mathrm{Y} a$; other peaks were $\pm 0.86 \mathrm{e} \AA^{-3}$. Scattering factors were taken from Cromer \& Waber (1974) and dispersion corrections $\left(f^{\prime}\right)$ from Cromer (1974). Programs used were those of the CRYM crystallographic computing system (Duchamp, 1964) and ORTEPII (Johnson, 1976). Final heavy-atom parameters are given in Table 1.*

Discussion. Fig. 1 shows labeled drawings of molecules $A$ and $B$; selected distances and angles for these are given in Table 2. Because the two molecules are so similar, this discussion uses average distances with the scatter standard deviation given in square brackets. Fig. 2 shows the unit-cell packing. The

* Lists of assigned $\mathrm{H}$-atom parameters, anisotropic displacement parameters, complete distances and angles, and observed and calculated structure factors have been deposited with the British Library Document Supply Centre as Supplementary Publication No. SUP 55177 (75 pp.). Copies may be obtained through The Technical Editor, International Union of Crystallography, 5 Abbey Square, Chester CH1 2HU, England. [CIF reference: HH0616]

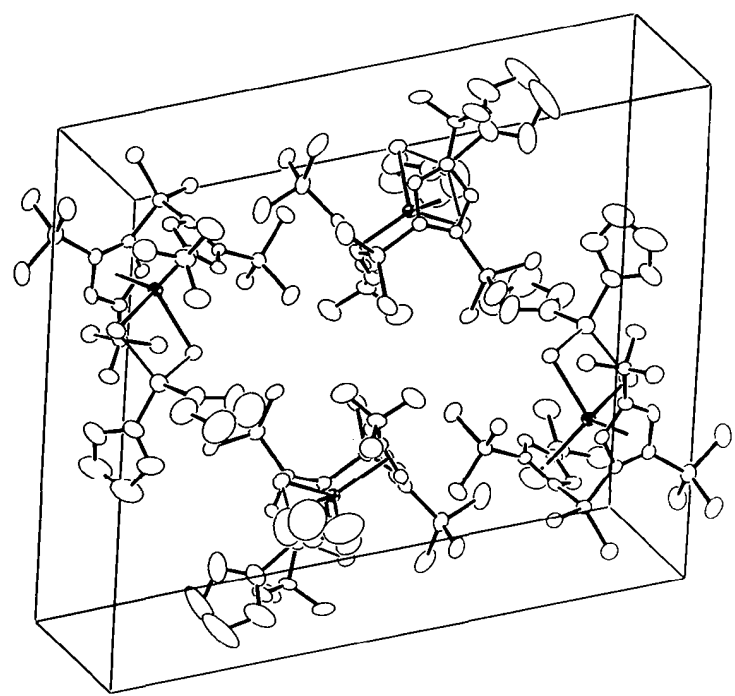

Fig. 2. An ORTEPII (Johnson, 1976) view of the contents of a unit cell, with one unit cell outlined. $Y$ atoms have their principal ellipsoids outlined. Atoms are shown as $50 \%$ probability ellipsoids and $\mathrm{H}$ atoms are omitted. The $c$ axis is horizontal and the view is perpendicular to the $b c$ plane. The $A$ molecules are closer to the center of the cell and the $B$ molecules are in the upper-left and lower-right corners. 
centroids of the $\mathrm{Cp}$ rings are 2.388 [6] $\AA$ from the $\mathrm{Y}$ atoms, but the $\mathrm{Cp}$ planes are not perpendicular to the $\mathrm{Y}-\mathrm{Cp}$ vectors. $\mathrm{Y}-\mathrm{C}(\mathrm{Cp}$ ring $)$ distances range from 2.585 (5) to 2.817 (6) $\AA$, with the $\mathrm{C}$ atoms closest to the Si bridge being closest to Y. This effect is caused by the bridging $\mathrm{Si}$ atom; it 'pinches' the $\mathrm{Cp}$ rings together and the $Y$ atom can no longer fit between them perfectly. This effect is also seen in the angle between the two $\mathrm{Cp}$ planes: this is $113(4)^{\circ}$, whereas the $\mathrm{Cp} 1-\mathrm{Y}-\mathrm{Cp} 2$ angle is $122.3^{\circ}$. (The $\mathrm{Cp}(\mathrm{C})-\mathrm{Sil}-\mathrm{Cp}(\mathrm{C})$ angle is $99.3[3]^{\circ}$.\} Other distances in the $\mathrm{Y}$ molecule are normal: $\mathrm{Y}-\mathrm{Cl}$ 2.627 [12], $\mathrm{Si}-\mathrm{C} 1.863$ [12], $\mathrm{C}-\mathrm{C}$ ( $\mathrm{Cp}$ rings) $1.422[17] \AA$. In each molecule there is a strain evidenced by two normal $\mathrm{C}(\mathrm{Cp})-\mathrm{Si}-\mathrm{CH}_{3}$ angles of $108.4[4]^{\circ}$ and a third larger angle of $117.0[10]^{\circ}$, to the methyl $\mathrm{C}$ atom near the other $\mathrm{Cp}$ ring. This strain appears in all four independent $\mathrm{Cp}$ rings and reflects a steric crowding between the $-\mathrm{Si}\left(\mathrm{CH}_{3}\right)_{3}$ group and the rest of the molecule: from the affected $\mathrm{CH}_{3}$ group, $\mathrm{C}-\mathrm{C}$ distances are 3.81 [4] $\AA$ to a methyl $\mathrm{C}$ atom on the $\mathrm{Si}$ bridge $(\mathrm{Cl}$ or $\mathrm{C} 2)$, $4.02[5] \AA$ to a methyl $\mathrm{C}$ atom on the ${ }^{\mathrm{B}} \mathrm{Bu}$ group of the opposite bridge and only $3.68[3] \AA$ to a $\mathrm{Cp} \mathrm{C}$ atom in the opposite $\mathrm{Cp}$ ring. The 'radius' of a $-\mathrm{CH}_{3}$ group is taken as $2.0 \AA$; thus the first contact is $0.09 \AA$ short while the second is at just the van der Waals distance. The $3.68 \AA$ contact is short enough to imply the severe strain of bending a $\mathrm{C}-\mathrm{Si}-\mathrm{C}$ bond by $8^{\circ}$ or so.

The $\mathrm{Li}(\text { thf })_{2}^{+}$group is joined to the two $\mathrm{Cl}$ atoms of the $\mathrm{Y}$ molecule, with $\mathrm{Li}-\mathrm{Cl}$ distances averaging
$2.371[25] \AA$, almost exactly the sum of the crystal radii for $\mathrm{Li}^{+}$and $\mathrm{Cl}^{-}$and shorter than the $\mathrm{Li}-\mathrm{C}$ distance $(2.57 \AA)$ in $\mathrm{LiCl}$ (Wells, 1962). Coordination about the $\mathrm{Li}^{+}$atom is approximately tetrahedral (Fig. 1), with normal $\mathrm{Li}-\mathrm{O}$ distances $\{1.92[2] \AA$ $\}$. The thf molecules have large apparent thermal motions, indicating a moderate disorder.

This work has been supported by the USDOE Office of Basic Energy Sciences (Grant No. DEFG03-85ER113431) and by Exxon Chemicals Americas.

\section{References}

CROMER, D. T. (1974). International Tables for X-ray Crystallography, Vol. IV, pp. 149-151. Birmingham: Kynoch Press. (Present distributor Kluwer Academic Publishers, Dordrecht.)

Cromer, D. T. \& WABER, J. T. (1974). International Tables for $X$-ray Crystallography, Vol. IV, pp. 99-101. Birmingham: Kynoch Press. (Present distributor Kluwer Academic Publishers, Dordrecht.)

DuCHAMP, D. J. (1964). CRYM crystallographic computing system. Am. Crystallogr. Assoc. Meet., Bozeman, Montana. Paper B14, p. 29.

JOHNSON, C. K. (1976). ORTEPII. Report ORNL-3794, revised. Oak Ridge National Laboratory, Tennessee, USA.

Piers, W. E., Shapiro, P. J., Bunel, E. E. \& Bercaw, J. E. (1990). Synlett, 2, 74-84.

Roll, W., Brintzinger, H. H., RIEGer, B. \& ZolK, R. (1990). Angew. Chem. Int. Ed. Engl. 29, 279-280.

Wells, A. F. (1962). Structural Inorganic Chemistry, 3rd edition, p. 357. Oxford Univ. Press.

Wiesenfeldt, H., Reinmuth, A., Barsties, E., Evertz, K. \& BrINTZINGER, H. H. (1989). J. Organomet. Chem. 369, 359-370.

Acta Cryst. (1992). C48, 1776-1778

\title{
A Bis(pyrazolyl)(bipyridyl)platinum Complex
}

\author{
By William P. Schaefer, William B. Connick, Vincent M. Miskowski and Harry B. Gray \\ Division of Chemistry and Chemical Engineering* and The Beckman Institute, Mail Code 139-74, \\ California Institute of Technology, Pasadena, California 91125, USA
}

(Received 26 December 1991; accepted 11 February 1992)

\begin{abstract}
Dimethyl-2,2'-bipyridyl)bis(3,5-dimethylpyrazolium)platinum(II) 0.5-tetrahydrofuran solvate monohydrate, $\left[\mathrm{Pt}\left(\mathrm{C}_{5} \mathrm{H}_{7} \mathrm{~N}_{2}\right)_{2}\left(\mathrm{C}_{12} \mathrm{H}_{12}-\right.\right.$ $\left.\mathrm{N}_{2}\right)$ ].0.5 $\mathrm{C}_{4} \mathrm{H}_{8} \mathrm{O} . \mathrm{H}_{2} \mathrm{O}, M_{r}=623.65$, monoclinic, $P 2_{1} / n$, $a=8.625(2), b=20.593(8), c=14.451$ (4) $\AA, \beta=$ $90.32(2)^{\circ}, \quad V=2566.7(14) \AA^{3}, \quad Z=4, \quad D_{x}=$

* Contribution No. 8555 .
\end{abstract}

0108-2701/92/101776-03\$06.00
$1.61 \mathrm{~g} \mathrm{~cm}^{-3}, \quad \lambda($ Mo $K \alpha)=0.71073 \AA, \quad \mu=$ $55.50 \mathrm{~cm}^{-1}, F(000)=1232$, room temperature, $R=$ 0.0387 for 2874 reflections with $F_{o}^{2}>3 \sigma\left(F_{o}^{2}\right)$. The square-planar $\mathrm{Pt}$ complex has normal $\mathrm{Pt}-\mathrm{N}$ (bipyridyl) bonds [2.009 (8) $\AA]$ and slightly short $\mathrm{Pt}-\mathrm{N}($ pyrazolyl) bonds [1.983 (7) $\AA$ ]. The ligand molecules have normal distances and angles; the planes of the pyrazolyl ligands are twisted by about

(C) 1992 International Union of Crystallography 